\title{
Radiation and Geochemical Assessment of the Soil State in the South of Tyumen Region
}

\author{
Leonid Skipin ${ }^{1, *}$,Elena Zakharova ${ }^{1}$, Elena Gaevaya ${ }^{1}$, Vasilya Burlaenko ${ }^{1}$, and Aleksandr \\ Mitrikovskiy ${ }^{1}$ \\ ${ }^{1}$ Industrial University of Tyumen, 625001 Volodarskogo str. 38, Tyumen, Russia
}

\begin{abstract}
The article presents a study of the radiation and geochemical background state of soil in the south of Tyumen region. According to the obtained data it was revealed that within the study areas, the power values of gamma radiation exposure dose ranged from 6 to $12.5 \mathrm{mcR} / \mathrm{h}$, due to the natural gamma background of the area. The research results of the soils radiation status have shown that the main contribution to the radiation activity of soils is made by the natural radionuclide potassium- 40 and manmade strontium-90. Elevated concentration of strontium-90 was observed in grey forest soils and amounted to $102 \mathrm{~Bq} / \mathrm{kg}$. The study of soil radiation contamination in the "Tavda" explosion epicenter (Nizhnetavdinsky district) revealed the dynamics of migration of radionuclides along the soil profile, which takes place at a considerable depth $(80-100 \mathrm{~cm})$. The maximum concentration of strontium- 90 was observed in the area "South$200 "$ at the soil layer of $10-20 \mathrm{~cm}$ depth and was $1680 \mathrm{~Bq} / \mathrm{kg}$. The presence of heavy metals mobile forms in the soils of the Tyumen region south is within the MPC. The article presents a mathematical processing of the obtained results.
\end{abstract}

\section{Introduction}

Soil cover of the biosphere is one of the main components in nature, in which radionuclides and heavy metals are located due to the fact that man discharges them into the environment as a result of his anthropogenic activities [1-21]. When it comes to the artificial radionuclides and heavy metals, soil has a unique sorption capacity that implies an ambivalent meaning for their migration in the biosphere [3, 16, 17]. Specific features of radionuclides sorption by soil absorbing complex provide their strong retention in the terrestrial compartment with a long half-life $[1,14,15,19]$.

In biological chain, soil is one of the main ways by which radionuclides and heavy metals get into the feeding and food plants, and through them - into animals and humans $[4,18,20]$. Due to the construction of an underground oil storage tank in Nizhnetavdinsky District in 1959, as well as the consequences of the East Ural Radioactive Trace and the accident at "Mayak", there is a necessity to check the possibility of artificial radionuclides

\footnotetext{
Corresponding author: tgasu.skipin.leonid@,mail.ru,
} 
entering the territory of Tyumen region. It is possible that radionuclides cesium-137 and strontium-90 will enter Tyumen region. [10,12].

Technological impact of long-lived radionuclides and heavy metals located in natural objects caused contamination of large areas. Consequently, to assess the ecological status of the ecosystem units, there occurred a need of monitoring research of the artificial radionuclides and heavy metals presence in the region $[2,8,9,10,13]$.

\section{Subjects and Methods}

The subject of the research is the soil selected on the benchmark areas located in the territory of the administrative districts at a depth of $0-20 \mathrm{~cm}$ in the upper horizontal layer of soil. In the area of Nizhnetavdinsky district, in the center of underground tank construction, sampling was carried out at a depth of 0-10, 10-20, 40-60, 80-100 cm. The samples are represented by the following soil types: sod-podzolic, deep dark grey podzolized, leached chernozem, sod-podzolic gley, grey forest podzolized, grey forest, grey forest podzolized of medium depth, light grey forest.

Sampling was carried out in the south of Tyumen region for the further analysis in accordance with GOST 17.4.3.01-81, GOST 17.4.402-84, GOST 28168-89. The samples were tested in the "Radiation monitoring", "Environmental monitoring" laboratories at the Safety of Technosphere Department of TSUACE.

Radiometry of soil samples was measured with the "Progress" spectrometric complex. The presence of cesium-137 radionuclides was revealed by the scintillation gamma-ray spectrometry, and strontium-90 presence was revealed by scintillation beta-ray spectrometry in the native material. Detection of heavy metals in soil samples was carried out by stripping voltammetry at the "CTA" voltammetry complex and "Temos-Express" complex of sample preparation. EDR (exposure dose rate) of gamma radiation was measured with DRG 01 T1 dosimeter.

\section{Results}

The level of natural radiation background depends on the concentrations of natural of radionuclides (radium-226, thorium-232 and potassium-40) in the Earth surface, water, air and other elements of the biosphere. Technologically changed natural radiation background is generated from natural sources of ionizing radiation as a result of radionuclides extraction from the earth interior, along with minerals or building materials [21]. Selfpurification of the atmosphere upper layers from natural and man-made radionuclides is a slow process, which continues to be a global source of radioactive contamination of the environment. The source of contamination of surface layer atmosphere is the wind-driven rise of radioactive substances from the soil surface in areas contaminated due to nuclear weapons tests and accidents at enterprises of nuclear fuel cycle [11, 12].

The exposure dose rate (EDR) values of gamma-radiation in the southern areas of Tyumen region ranged from 6 to $12.5 \mathrm{mcR} / \mathrm{h}$, due to the natural gamma background of the territory which does not exceed the established reference levels of $15 \mathrm{mcR} / \mathrm{h}$ for Tyumen region (Fig.1). The maximum EDR values of gamma radiation have been observed in Vagaysky Disrtict (12.27 mcR/h), Omutinsky District (10.82 mcR/h) and Aromashevsky District $(10,10 \mathrm{mcR} / \mathrm{h})$. It should be noted that increased EDR values were observed in the regions bordering the Omsk region and Kazakhstan. This can be explained by the possible impact of the Semipalatinsk test site and the high concentration of NRN in the earth surface. Minimum rates were recorded in Yalutorovsk $(6.23 \mathrm{mcR} / \mathrm{h})$ and Tobolsk Districts $(6.46 \mathrm{mcR} / \mathrm{h})$. 


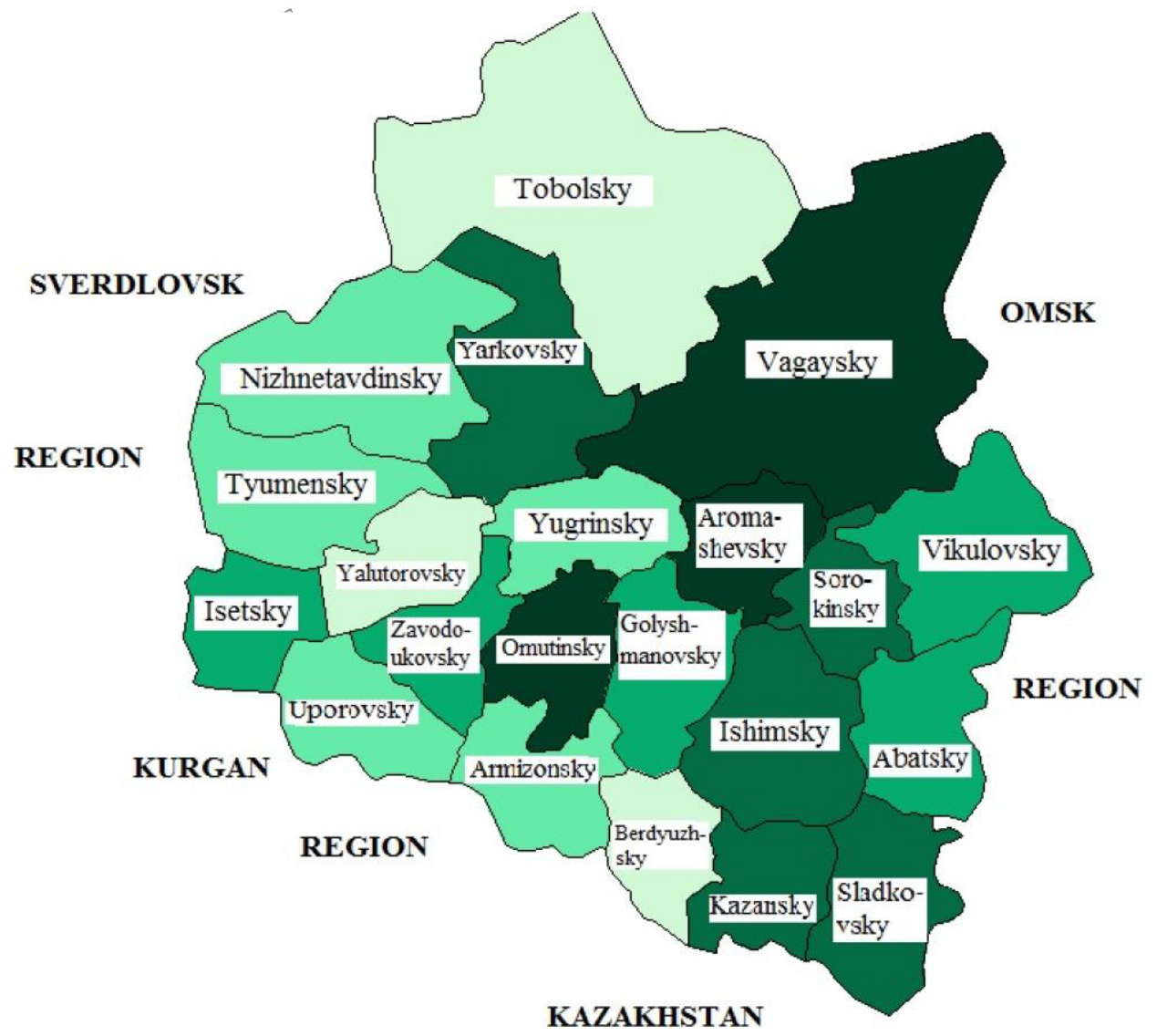

\section{Gamma-radiation EDR, McR/h}

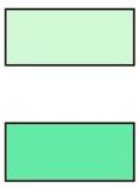

$6,23-6,90$

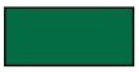

$8,36-8,72$

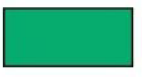

$$
6,23-6,90
$$

$7,01-7,96$

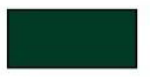

$9,02-9,81$

$10,10-12,27$

Fig. 1. Exposure dose rate of gamma-radiation on the south of Tyumen region (average values).

Fig. 2 presents the research of soils for the presence of natural and man-made radionuclides in the upper horizontal layer $(0-20 \mathrm{~cm})$ in 6 control districts in the south of Tyumen region.

The diagram shows that the natural radionuclide potassium- 40 and artificial strontium90 mostly contribute to the radiation state of soils. The maximum values of the potassium40 concentration were observed in Vagaysky $(926 \mathrm{~Bq} / \mathrm{kg})$ and Nizhnetavdinsky $(719 \mathrm{Bk} / \mathrm{kg})$ Districts. Presence of strontium-90 was 102 and $95 \mathrm{~Bq} / \mathrm{kg}$ accordingly. Thus, the maximum strontium-90 concentration of $66.4 \mathrm{~Bq} / \mathrm{kg}$ was recorded in Vagaysky and Isetsky Districts, the minimum - in Ishimsky District $(36,3 \mathrm{Bk} / \mathrm{kg})$. Thorium-232 and cesium-137 had the minimum values of concentration that amounted to 18.2 and $4.5 \mathrm{Bg} / \mathrm{kg}$ in Ishimsky and Tyumensky Districts. 


\section{TPACEE-2016}

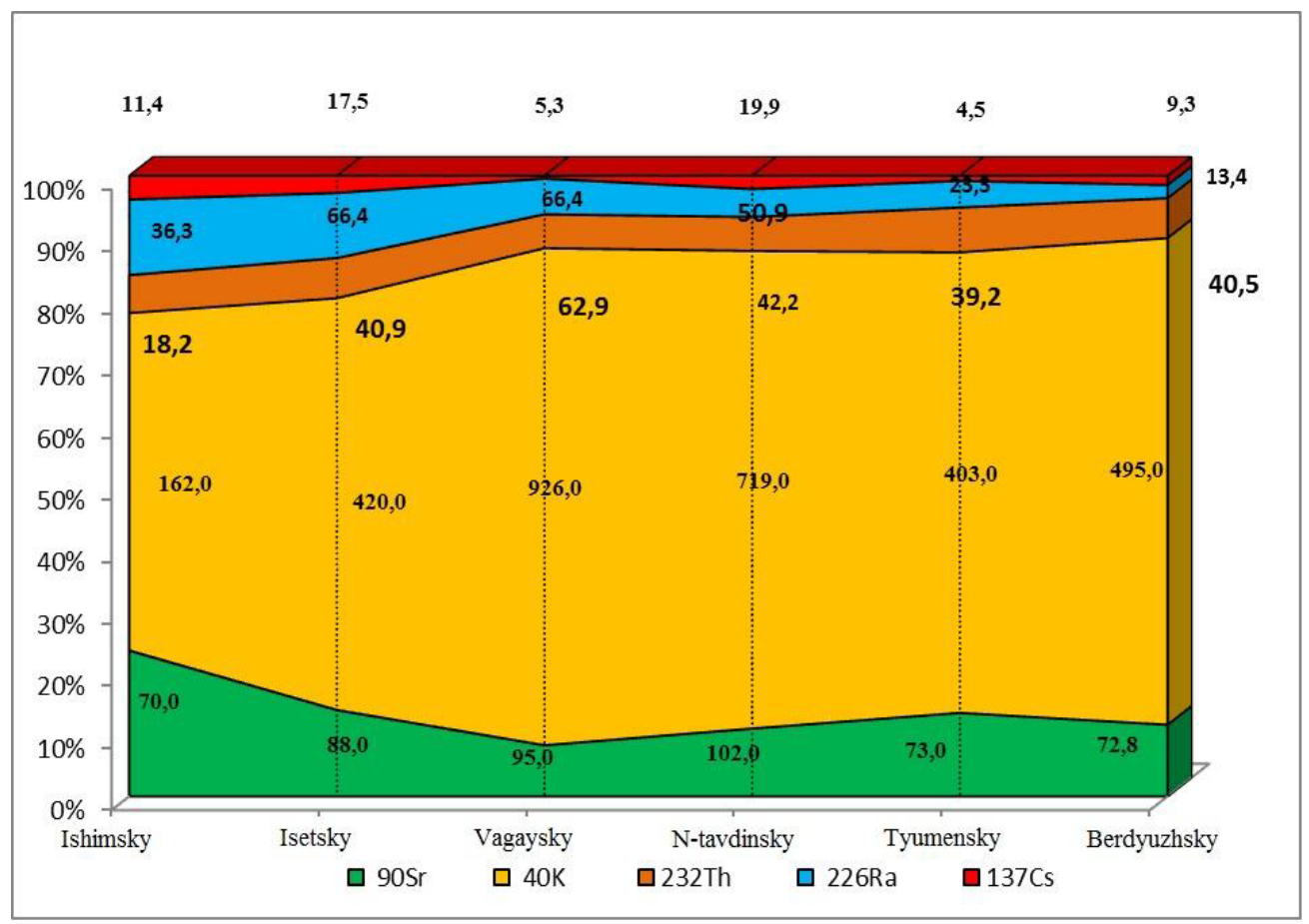

Fig. 2. Presence of natural and man-made radionuclides at a depth of $0-20 \mathrm{~cm}$ in control districts.

Figures 3 and 4 graphically represent the presence of cesium-137 and strontium-90 radionuclides in the soils of the control points.

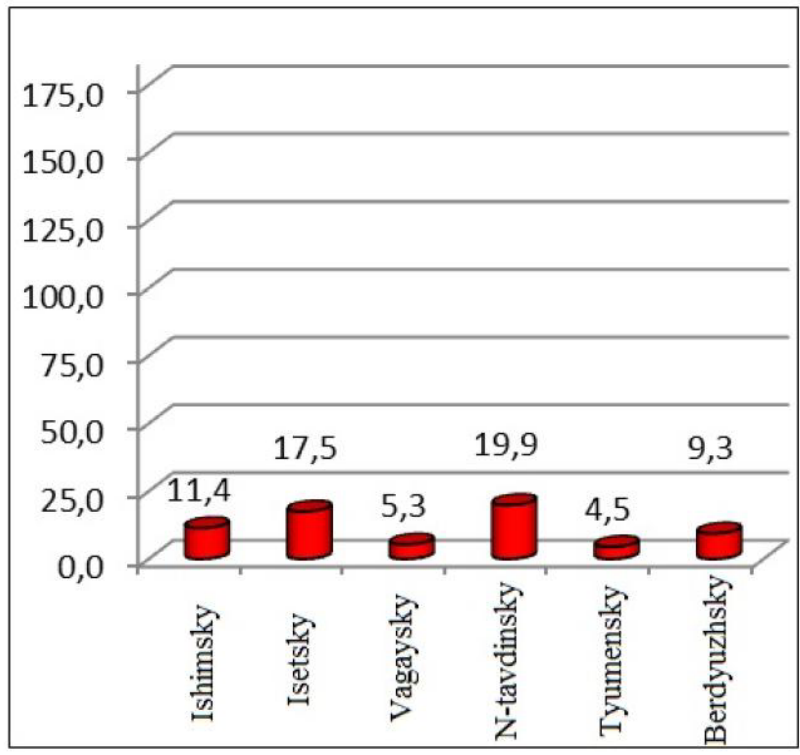

Fig. 3. graphically represent the presence of cesium- 137 radionuclides in the soils of the control points. 


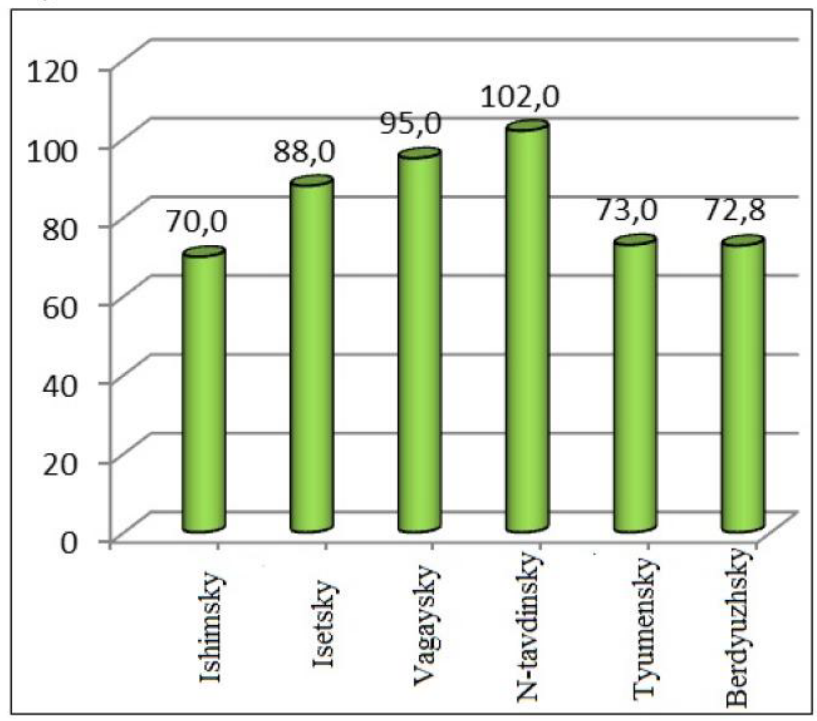

Fig 4. graphically represent the presence of strontium-90 radionuclides in the soils of the control points

Accumulation of radiocesium in soils is less intense than accumulation of radiostrontium. The highest concentration of both radionuclides was detected in Nizhnetavdinsky District.

The presence of cesium-137 in grey forest soils of Nizhnetavdinsky District was 19.9 $\mathrm{Bq} / \mathrm{kg}$, of strontium- $90-102 \mathrm{~Bq} / \mathrm{kg}$. The minimum amount of these elements was recorded in Tyumensky and Ishimsky Districts, which was $4.5 \mathrm{~Bq} / \mathrm{kg}$ and $70 \mathrm{~Bq} / \mathrm{kg}$, accordingly.

Research of the soils radiation state on the territory of the underground peaceful nuclear explosion "Tavda" gave the results, basing on which the concentrations of cesium-137 and strontium-90 were determined in a variety of soil profiles at a depth of $0-10,10-20,40-60$, $80-100 \mathrm{~cm}$ (Fig. 5, 7), as well as the density of radionuclides entering the soil was calculated - distance of $100 \mathrm{~m}$ and $200 \mathrm{~m}$ from the epicenter of the underground tank (Fig. 6 , 8).

Distribution of cesium-137 in a vertical soil profile is characterized by its maximum accumulation in the topsoil $(0-20 \mathrm{~cm})$, which is averagely more than $60 \%$ of its total presence in the root zone $(0-60 \mathrm{~cm})$.

Maximum lateral migration of radiocesium is observed in an easterly direction at a distance of 200 meters from the explosion.

The study of the vertical distribution of the gross amounts of cesium - 137 along the soil profiles showed that since the moment of soil contamination, radionuclides in these areas migrated to a considerable depth $(80-100 \mathrm{~cm})$.

The maximum concentration of this element was recorded at the site "East-200" in the soil of 10-20 cm depth and was $296.5 \mathrm{~Bq} / \mathrm{kg}$. 


\section{TPACEE-2016}

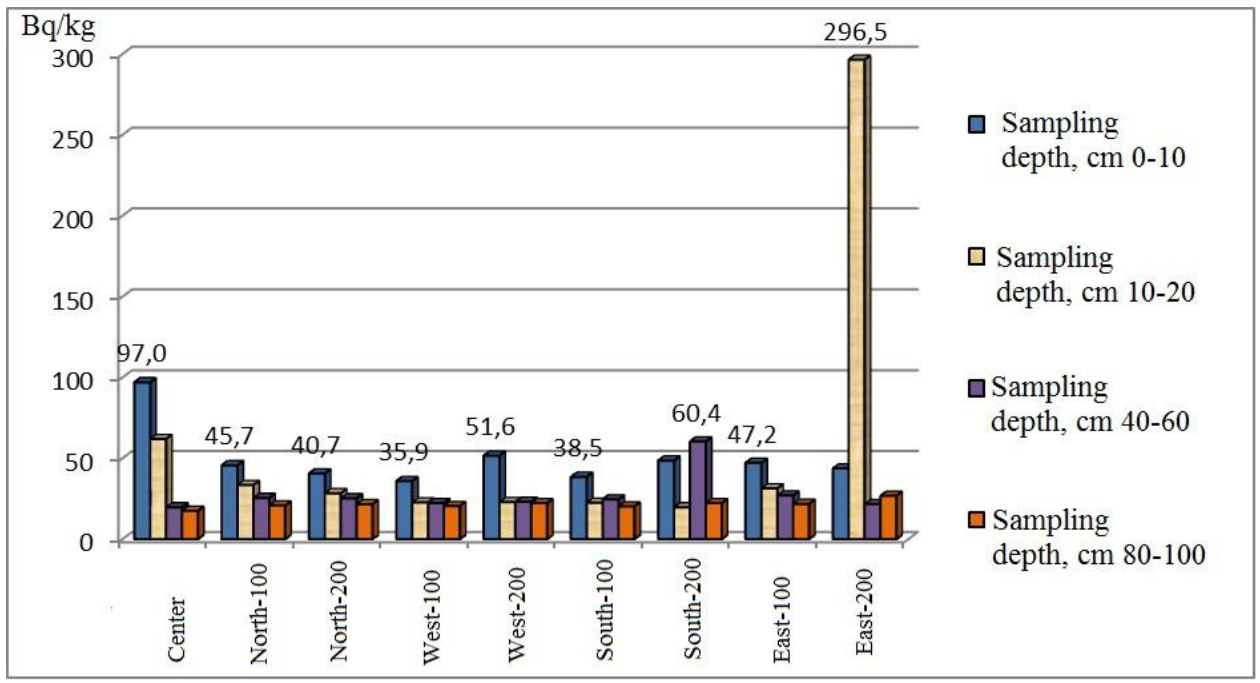

Fig. 5. Concentration of cesium-137 in the soil of Nizhnetavdinsky District at a distance of 100 and 200 meters from the explosion epicenter.

The density of the cesium-137 deposition into the soil (Fig. 6) is of steady rate in both vertical and horizontal directions, and varies from 0.146 to $0.141 \mathrm{Ci} / \mathrm{km} 2$.

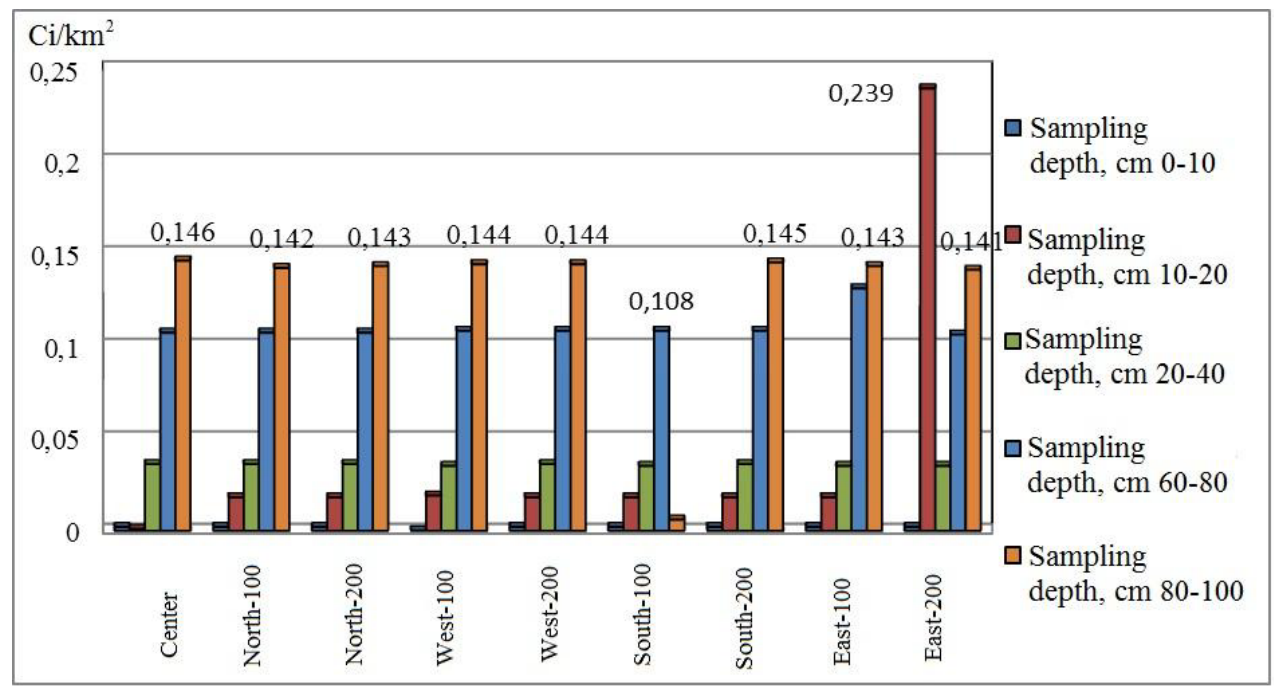

Fig. 6. The density of the cesium-137 deposition into the soil of Nizhnetavdinsky District at a distance of 100 and 200 meters from the explosion epicenter.

The basic mass of radionuclides is concentrated at a depth of $80-100 \mathrm{~cm}$ in all directions. The highest density of deposits was $0.239 \mathrm{Ci} / \mathrm{km} 2$ at a distance of 200 meters in an easterly direction and at a depth of $10-20 \mathrm{~cm}$, the lowest $-0.02 \mathrm{Ci} / \mathrm{km} 2$ in the layer of 0 $10 \mathrm{~cm}$ in all directions.

The accumulation of strontium-90 in grey forest soils is much more intense than accumulation of cesium. All soil profiles are characterized by the consistent pattern of increased concentration of a man-made element (Fig. 7). The maximum radionuclide concentration was observed at a depth of $10-20 \mathrm{~cm}$ in a southerly direction at a distance of $200 \mathrm{~m}$ from the epicenter, and was $1680 \mathrm{~Bq} / \mathrm{kg}$. 


\section{TPACEE-2016}

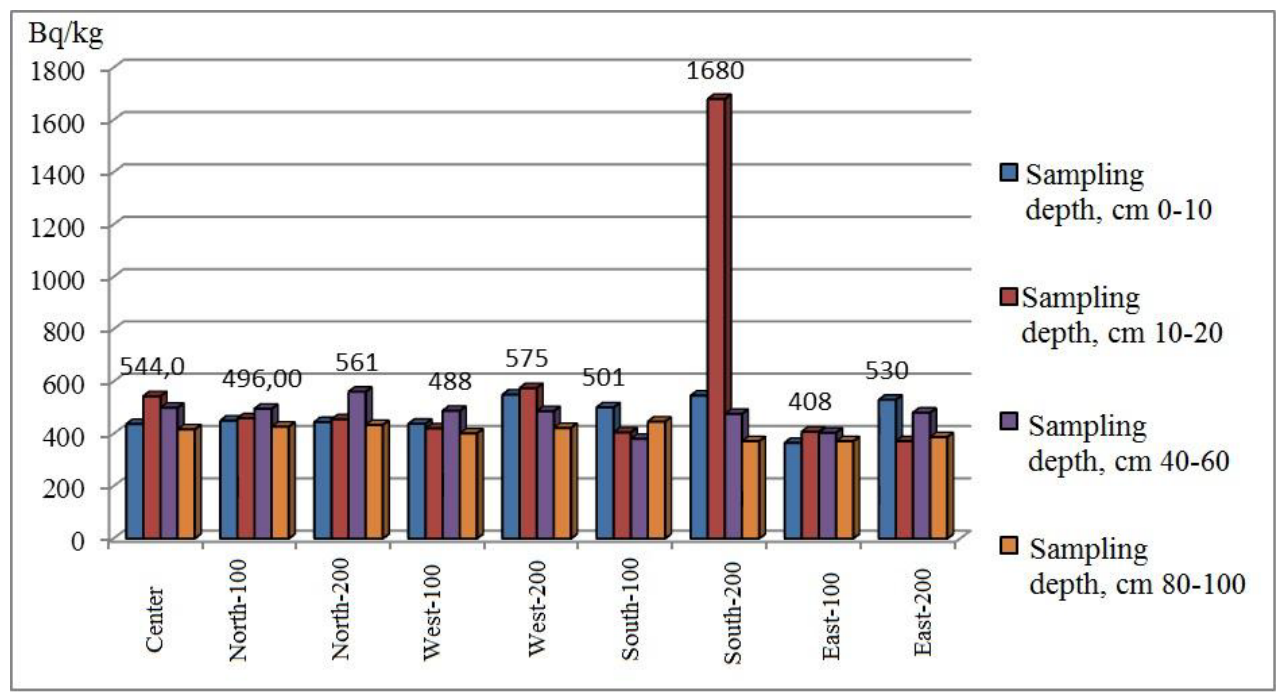

Fig. 7. Concentration of strontium-90 in the soil of Nizhnetavdinsky District at a distance of 100 and 200 meters from the explosion epicenter.

Density of strontium-90 deposition tends to increase with depth of the soil profiles (Fig. $8)$. In the upper layers of the soil $(0-10 \mathrm{~cm})$ inactivation of strontium- 90 was more intense, and deposition density here does not exceed $0.04 \mathrm{Ci} / \mathrm{km} 2$. This fact can be explained by the increased aeration of the upper level, the filtration capacity and biological activity. The maximum density of strontium deposition was observed in the epicenter of the explosion at the depths of $40-100 \mathrm{~cm}$. The layer of $80-100 \mathrm{~cm}$ at the epicenter of the explosion is mostly subjected to contamination, the deposition density here reached $3.464 \mathrm{Ci} / \mathrm{km} 2$. In the points North-100, West-100, South-100, East-100, the indicators of soil contamination density amounted to $2.906 ; 2.827 ; 0.126 ; 2.432 \mathrm{Ci} / \mathrm{km} 2$ accordingly. This dynamics maintained in samples taken at a distance of 200 meters from the epicenter of the explosion, and concentration of strontium- 90 in the layer of $80-100 \mathrm{~cm}$ decreased by $0.2-0.4 \mathrm{Ci} / \mathrm{km} 2$ on average.

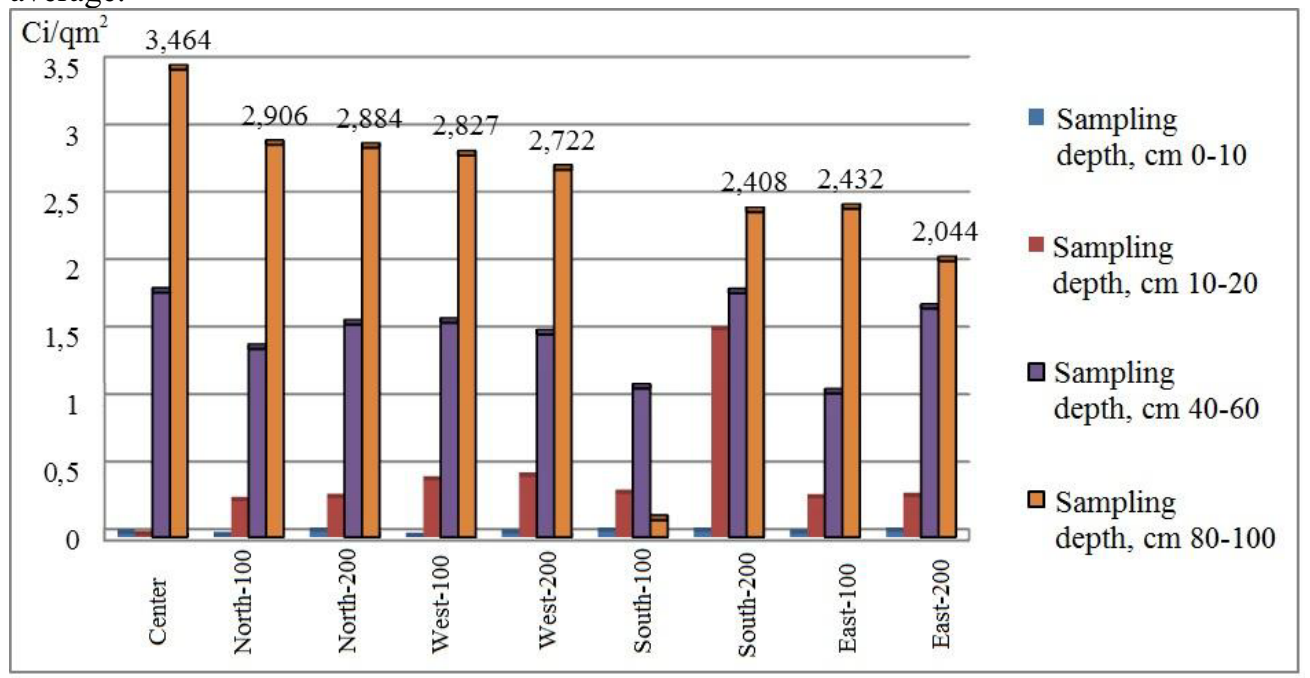

Fig. 8. Density of the strontium-90 deposition into the soil of Nizhnetavdinsky District at a distance of 100 and 200 meters from the explosion epicenter. 
Results of the research of the "Tavda" explosion venue raise the possibility of cesium137 going out of the mouth of the well drilled into the blast zone.

In accordance with the classification of territories ranged in the degree of ecological trouble (Table 1), the soil in the epicenter of the "Tavda" underground explosion can be attributed to the areas of the environmental emergency.

Table 1. Criteria for environmental assessment of the soils state.

\begin{tabular}{|c|c|c|c|c|c|}
\hline Criteria & $\begin{array}{c}\text { Ecological } \\
\text { disaster, } \\
{\left[\mathrm{Ci} / \mathrm{km}^{2}\right]}\end{array}$ & $\begin{array}{c}\text { Environmental } \\
\text { emergency, } \\
{\left[\mathrm{Ci}^{2} / \mathrm{km}^{2}\right]}\end{array}$ & $\begin{array}{c}\text { Satisfactory } \\
\text { situation, } \\
{\left[\mathrm{Ci} / \mathrm{km}^{2}\right]}\end{array}$ & $\begin{array}{c}\text { Area of } \\
\text { the } \\
\text { time, } \\
{[\text { years }]}\end{array}$ & $\begin{array}{c}\text { assessed } \\
\text { territory, } \\
{[\text { thousand }} \\
\text { hectares }]\end{array}$ \\
\hline $\begin{array}{c}\text { Radioactive } \\
\text { contamination of } \\
\text { soils with cesium- } \\
137 .\end{array}$ & Over 40 & $15-40$ & Less than 1 & 1 & 0.1 \\
\hline $\begin{array}{c}\text { Radioactive } \\
\text { contamination of } \\
\text { soils with } \\
\text { strontium-90. }\end{array}$ & Over 3 & $1-3$ & $\begin{array}{c}\text { Less than } \\
0.3\end{array}$ & 1 & 0.1 \\
\hline
\end{tabular}

Radioactive contamination of soil in layers of 40-60, 60-80, 80-100 cm with strontium90 was recorded in the range of 1 to $3 \mathrm{Ci} / \mathrm{km} 2$. In the central point of sampling the concentration of strontium-90 at a depth of $80-100 \mathrm{~cm}$ was $3.464 \mathrm{Ci} / \mathrm{km} 2$.

Taking into account the classification of areas ranged in the degree of ecological trouble, this soil can be characterized as a zone of ecological disaster.

In the upper layers of soil (up to $40 \mathrm{~cm}$ ) the density of contamination with strontium-90 does not exceed $1 \mathrm{Ci} / \mathrm{km} 2$, which means that this zone can be attributed to the territory with a satisfactory situation.

Concentration of the mobile forms of heavy metals, acidity and humus in the soil samples was studied in the laboratories of TSUACE. Basing on the results it can be stated that the presence of the mobile forms of heavy metals in the soils of Tyumen region south is within the MPC and can be assessed as "low".

These indicators show that southern territory of Tyumen region is ecologically clean and is favorable for the cultivation of various crops.

Currently, volumes of soils liming are being reduced (in these conditions soil are acid and slightly acid, $\mathrm{pH}=5.59$ averagely), which will lead to the increased mobility of heavy metals.

Soil organic matter (humus) contributes to the binding of the mobile forms of heavy metals and to their transforming into insoluble compounds.

While heavy metals are firmly bound with the corresponding soil organic matters, they are remote for plants, and thus have less detrimental effect on the soil and plants.

Loss of humus in the soil is also able to induce the mobility of heavy metals. This point is proved by some results of the research (Tab. 2). 
Table 2. Average data of the mobile forms of heavy metals, humus and acidity in the soils of the southern part of Tyumen Region, 2012-2015.

\begin{tabular}{|c|c|c|c|c|c|c|c|}
\hline District & {$[\mathrm{Zn}]$} & {$[\mathrm{Cu}]$} & {$[\mathrm{Cd}]$} & {$[\mathrm{Pb}]$} & $\begin{array}{c}\text { Humus. } \\
{[\%]}\end{array}$ & {$[\mathrm{pH}]$} \\
\hline Taiga-forest zone & $1.14 \pm 0.34$ & $0.43 \pm 0.13$ & $0.09 \pm 0.03$ & $1.79 \pm 0.54$ & 4.20 & 5.30 \\
\hline Tobolsky & $1.49 \pm 0.45$ & $0.34 \pm 0.10$ & $0.12 \pm 0.04$ & $1.51 \pm 0.45$ & 3.60 & 5.40 \\
\hline Vagaysky & $\begin{array}{c}\text { Sub-Boreal } \\
\text { Forest }\end{array}$ \\
\hline \multicolumn{7}{|c|}{ South Taiga } \\
\hline Nizhnetavdinsky & $0.82 \pm 0.25$ & $0.31 \pm 0.09$ & $0.08 \pm 0.02$ & $2.46 \pm 0.74$ & 3.70 & 5.20 \\
\hline Yarkovsky & $1.20 \pm 0.36$ & $0.51 \pm 0.15$ & $0.07 \pm 0.02$ & $1.77 \pm 0.53$ & 4.10 & 5.60 \\
\hline Yurginsky & $0.57 \pm 0.17$ & $0.30 \pm 0.09$ & $0.06 \pm 0.02$ & $3.04 \pm 0.91$ & 4.30 & 5.40 \\
\hline Aromashevsky & $<0.01$ & $<0.05$ & $<0.01$ & $<0.10$ & 4.50 & 5.40 \\
\hline Vikulovsky & $<0.01$ & $<0.05$ & $<0.01$ & $<0.10$ & 4.80 & 5.50 \\
\hline Sorokinski & $<0.01$ & $<0.05$ & $<0.01$ & $<0.10$ & 4.00 & 6.00 \\
\hline Forest-steppe zone & North Forest Steppe & & & \\
\hline Tyumensky & $1.39 \pm 0.41$ & $0.48 \pm 0.14$ & $0.08 \pm 0.02$ & $1.66 \pm 0.50$ & 5.50 & 5.70 \\
\hline Isetsky & $0.98 \pm 0.29$ & $0.42 \pm 0.13$ & $0.13 \pm 0.04$ & $1.86 \pm 0.56$ & 6.30 & 5.40 \\
\hline Yalutorovsky & $1.74 \pm 0.52$ & $0.64 \pm 0.19$ & $0.18 \pm 0.05$ & $1.20 \pm 0.36$ & 5.40 & 5.80 \\
\hline Zavodoukovsky & $1.07 \pm 0.32$ & $0.37 \pm 0.11$ & $0.12 \pm 0.04$ & $1.20 \pm 0.36$ & 6.50 & 5.30 \\
\hline Uporovsky & $0.47 \pm 0.14$ & $0.23 \pm 0.07$ & $0.07 \pm 0.02$ & $1.18 \pm 0.35$ & 5.80 & 5.40 \\
\hline Omutinsky & $0.90 \pm 0.27$ & $0.38 \pm 0.11$ & $0.06 \pm 0.02$ & $1.26 \pm 0.38$ & 6.00 & 5.50 \\
\hline Golyshmanovsky & $<0.01$ & $<0.05$ & $<0.01$ & $<0.10$ & 4.30 & 5.70 \\
\hline Ishymsky & $<0.01$ & $<0.05$ & $<0.01$ & $<0.10$ & 5.80 & 5.70 \\
\hline Abatsky & $<0.01$ & $<0.05$ & $<0.01$ & $<0.10$ & 5.30 & 5.80 \\
\hline Armizonsky & $1.07 \pm 0.32$ & $0.57 \pm 0.17$ & $0.08 \pm 0.02$ & $1.62 \pm 0.49$ & 6.10 & 5.40 \\
\hline Berdyuzhsky & $<0.01$ & $<0.05$ & $<0.01$ & $<0.10$ & 4.00 & 6.00 \\
\hline Kazansky & $<0.01$ & $<0.05$ & $<0.01$ & $<0.10$ & 5.40 & 5.90 \\
\hline Sladkovsky & $<0.01$ & $<0.05$ & $<0.01$ & $<0.10$ & 5.80 & 5.90 \\
\hline MPC/APC & 23.00 & 3.00 & 0.50 & 6.00 & & \\
\hline
\end{tabular}

When the presence of humus is $4.3 \%$ (Yurginsky District), the concentration of mobile forms of lead is $3.04 \mathrm{mg} / \mathrm{kg}$. If humus is $6.1 \%$ (Armizonsky District), $6.5 \%$ (Zavodoukovsky Disrtict), then lead - 1.62 and $1.20 \mathrm{mg} / \mathrm{kg}$, accordingly. Rather significant correlation dependence was observed only between the humus presence and the mobile lead $(\mathrm{r}=-0.54)$. Zinc and copper show insignificant dependence on the presence of organic matter in the soil. This can be explained by the fact that these chemical elements intensively form tightly bound complexes with mineral colloidal fractions. It is important to note that soils of the southern part of Tyumen region are characterized as heavy-textured.

After analyzing the correlation dependence between the heavy metals and agrochemical parameters (humus and soil acidity) it can be stated that mechanisms of the metals retention 
in soil include: adsorption on the surface of the humus, formation of complex compounds with humus, and formation of insoluble compounds, especially within remediation, when reaction of the environment plays an important role. There is an inverse relation $(r=$ from 0.30 to -0.90 ) between the humus presence and the mobility of heavy metals which means that with increase of humus, the mobility of heavy metals decreases. The data of correlation analysis of soil acidity and mobile forms of heavy metals have different characteristics. There is a direct dependence between the acidity and the presence of cadmium mobile forms $(r=0.68)$; an inverse relation - between acidity and lead $(r=-0.69)$. Positive coefficient of correlation presumes that with the increase of the first characteristic, the second one increases as well. Negative coefficient presumes that with the increase of acidity, the mobility of zinc and lead decreases.

Mathematical processing of the results (Table 1) showed a significant variability, the coefficient of variation of all the elements is over $20 \%$. Lead has the greatest degree of dispersion $(\mathrm{V}=88 \%)$, copper is the least susceptible to variations $(\mathrm{V}=60 \%)$. According to the degree of variation heavy metals form the following decreasing series: $\mathrm{Pb}>\mathrm{Cd}>\mathrm{Zn}>$ $\mathrm{Cu}$.

Beyond that, the presence of some heavy metals determines the presence or, on the contrary, absence of the other. The increase of the lead mobility is directly proportional to the zinc mobility $(r=0.70)$ and inversely proportional to the mobility of cadmium $(r=-$ 0.92 ). Change in the presence of copper is directly proportional to the change in the zinc presence $(r=0.44)$.

\section{Conclusion}

After analyzing the concentration of cesium-137 and strontium-90 radionuclides in soils of the southern parts of Tyumen region, it can be concluded that soil contains small quantities of radionuclides, and the natural gamma background is within the norm.

The dose rate of gamma radiation at a height of $1 \mathrm{~m}$ from the ground surface varied from 6 to $12.5 \mathrm{mcR} / \mathrm{h}$, which corresponds to the natural background radiation, and does not exceed the norm of $15 \mathrm{mcR} / \mathrm{h}$ for Tyumen region. These results do not raise serious environmental concerns. Besides, by taking the agrotechnical measures, one can significantly reduce the concentration and proximity of these radionuclides in the treated soils.

Analysis of the data on concentrations of the man-made radionuclides in the soil of the "Tavda" underground explosion epicenter (Nizhnetavdinsky District) refers to a local crisis in the deep layers of the soil profile, as well as the need for continuous radiation monitoring of the area.

Soils examination for heavy metals concentration showed that they do not exceed the MPC, although they are unevenly distributed in the surveyed areas. As for mobility in the soil, metals form the following row: $\mathrm{Pb}>\mathrm{Cd}>\mathrm{Zn}>\mathrm{Cu}$. With the increase of soil acidity, about $50 \%$ of cadmium evolves into mobile form, and about $50 \%$ of lead, on the contrary, is bound by the soil organo-mineral complex in the forms inaccessible for plants. Beyond that, with increasing zinc mobility, the mobility of lead increases as well.

With the increase of the lead proximity, the concentration of cadmium mobile forms reduces.

The dependence between the humus concentration and heavy metals is weak, so it is impossible to say for sure whether this characteristic does or doesn't influence on the mobility of heavy metals in soil. Geochemical situation in the south of Tyumen region can be described as weakly exposed to the technogenic contamination. 


\section{References}

1. A.G. Berseneva, Sbornik materialov XV nauchno-prakticheskoy konferentsii molodykh uchenykh, aspirantov, soiskateley i magistrantov TyumGASU, 16-21 (2015)

2. A.G. Berseneva, Aktual'nye problemy stroitel'stva, ekologii i energosberezheniya v usloviyakh Zapadnoy Sibiri: sbornik materialov Mezhdunarodnoy nauchnoprakticheskoy konferentsii, 153-156 (2014)

3. L.A. Bol'shov, Rol' radiatsionnykh faktorov v ekologicheskikh riskakh dlya naseleniya Rossii: TSNII atominform, 29-32 (2001)

4. A.A. Vaymer, DSc Thesis (Tyumen, 2006)

5. E.V. Gaevaya, Vestnik Krasnoyarskogo gosudarstvennogo agrarnogo universiteta, 11, 149-153 (2013)

6. E.V. Gaevaya, Visnik Dnipropetrovs'kogo derzhavnogo agrarnogo universitetu, 2(34), 99-102 (2014)

7. G.P. Gamzikov, Plodorodie pochv i resursosberezhenie v zemledelii: materialy vseros. nauch.-prakt. konf., 20-27 (2003)

8. A.N. Guseynov, Ekologiya goroda Tyumeni: sostoyanie, problem (Slovo, Tyumen, 2001)

9. G.A. Demidenko, N.V. Fomina, Monitoring okruzhayushchey sredy (Krasnoyarsk, 2013)

10. V.A. Logachev, Mirnye yadernye vzryvy: obespechenie obshchey i radiatsionnoy bezopasnosti pri ikh provedeni (IzdAt, Tyumen, 2001)

11. E.V. Zakharova, Plodorodie, 6(81), 46-48 (2014)

12. E.V. Zakharova, Agroprodovol'stvennaya politika Rossii, 9, 88-92 (2013)

13. Kh. Zigel', A. Zigel', Nekotorye voprosy toksichnosti ionov metallov (Mir, 1993)

14. M.A. Kiseleva, Sbornik materialov XV nauchno-prakticheskoy konferentsii molodykh uchenykh, aspirantov, soiskateley i magistrantov TyumGASU. 43-49 (2015)

15. M.A. Kiseleva, Aktual'nye problemy arkhitektury, stroitel'stva, ekologii i energosberezheniya $\mathrm{V}$ usloviyakh Zapadnoy Sibiri: Sbornik materialov mezhdunarodnoy nauchno-prakticheskoy konferentsi, 227-232 (2015)

16. A.O. Oznobikhina, Sbornik materialov XV nauchno-prakticheskoy konferentsii molodykh uchenykh, aspirantov, soiskateley i magistrantov TyumGASU. 96-100 (2015)

17. A.O. Oznobikhina, Sbornik materialov XV nauchno-prakticheskoy konferentsii molodykh uchenykh, aspirantov, soiskateley i magistrantov TyumGASU, 92-96 (2015)

18. Yu.A. Sapozhnikov, R.A. Aliev, S.N. Kalmykov, Radioaktivnost' okruzhayushchey sredy. Teoriya i praktika (BINOM, Tyumen, 2006)

19. L.N. Skipin, Agroprodovol'stvennaya politika Rossii, 4(16), 29 (2014)

20. V.D. Starkov, Radiatsionnaya ekologiya (IPP “Tyumen"', Tyumen, 2001)

21. A.T. Khusainov, L.N. Skipin, L.I. Sofronova, Vliyanie otkhodov uranopererabatyvayushchikh predpriyatiy na sostoyanie komponentov ekosistem Severnogo Kazakhstana (Kokshetau, Tyumen, 2012) 